University of South Carolina

Scholar Commons

Faculty Publications

Chemistry and Biochemistry, Department of

$9-11-2008$

Oriented Cell Growth on Self-Assembled Bacteriophage M13 Thin Films

Jianhua Rong

Jinan University - China

L. Andrew Lee

University of South Carolina - Columbia

Kai Li

University of South Carolina - Columbia

Brandon Harp

University of South Carolina - Columbia

Charlene M. Mello

US Army Natick Soldier Research Development \& Engineering Center

See next page for additional authors

Follow this and additional works at: https://scholarcommons.sc.edu/chem_facpub

Part of the Bacteriology Commons, Biochemistry Commons, Medicinal-Pharmaceutical Chemistry Commons, Molecular Biology Commons, and the Organic Chemistry Commons

Publication Info

Published in Chemical Communications, Issue 41, 2008, pages 5185-5187.

(C) Chemical Communications 2008, Royal Society of Chemistry.

This Article is brought to you by the Chemistry and Biochemistry, Department of at Scholar Commons. It has been accepted for inclusion in Faculty Publications by an authorized administrator of Scholar Commons. For more information, please contact digres@mailbox.sc.edu. 


\section{Author(s)}

Jianhua Rong, L. Andrew Lee, Kai Li, Brandon Harp, Charlene M. Mello, Zhongwei Niu, and Qian Wang 


\title{
Oriented cell growth on self-assembled bacteriophage M13 thin films $\dagger$
}

\author{
Jianhua Rong, ${ }^{a b}$ L. Andrew Lee, ${ }^{b}$ Kai Li, ${ }^{b}$ Brandon Harp, ${ }^{b}$ Charlene M. Mello, ${ }^{c}$ \\ Zhongwei Niu*b and Qian Wang*b
}

\author{
Received (in Cambridge, UK) 28th June 2008, Accepted 28th August 2008 \\ First published as an Advance Article on the web 11th September 2008 \\ DOI: $10.1039 / \mathrm{b811039e}$
}

\begin{abstract}
Fibrillar M13 bacteriophages were used as basic building blocks to generate thin films with aligned nanogrooves, which, upon chemical grafting with RGD peptides, guide cell alignment and orient the cell outgrowth along defined directions.
\end{abstract}

Cell behavior is a complex orchestration of signaling between individual cells and their surrounding extracellular matrix (ECM). Understanding the biological intricacies between the cell and ECM is critical to answering general biological questions and the design of functional scaffolds for tissue engineering. Patterning and aligning scaffolds at the micro- and nanoscale with topographical features (indentations or grooves) as well as ligand organization have been reported to influence cell responses, such as oriented cell growth. ${ }^{1-4}$ Microcontact printing, ${ }^{5-7}$ photolithography ${ }^{8}$ and electrospinning ${ }^{9}$ have been extensively used to design indentations and grooves at the micro- and nanoscale to systematically characterize cell behaviors towards such patterned surfaces. Here, we report a new system, comprising a thin film derived from self-assembled bacteriophage M13, which can be employed as a new scaffold to direct cell growth.

For years, bacteriophages and other viruses have been utilized as drug delivery vehicles and vaccines. ${ }^{10,11}$ The relatively simple chemistry and the facile genetic reprogramming of viruses placed these biological materials in the crosshairs of many materials scientists working to generate novel nanosized materials in the past decade. ${ }^{12,13}$ M13 bacteriophage, in particular, has been extensively characterized over the past years for use in phage display and inorganic material deposition. ${ }^{14,15}$ Its innate ability to organize into liquid crystals, along with its precisely-defined nanostructures, highly simplified molecular cloning strategies, and the ability to produce it rapidly in large quantities, are key features of a powerful nanoscale building block. ${ }^{16-20}$ In this study, we explored the natural tendency of M13 phage to form well-ordered films and the effects of such order on cell behavior.

To generate viral films, a phage suspension was slowly dried in 12-well plates over three days to yield liquid crystalline films. Similar to previous reports of M13 viral films, ${ }^{16}$ ordered

\footnotetext{
${ }^{a}$ Department of Materials Science and Engineering, Jinan University, Guangzhou 510632, P. R. China

${ }^{b}$ Department of Chemistry and Biochemistry and Nanocenter, University of South Carolina, Columbia, SC 29208, USA.

E-mail:niu.z@mail.chem.sc.edu; E-mail:wang@mail.chem.sc.edu ${ }^{c}$ Bioscience and Technology Team, US Army Natick Soldier Research Development \& Engineering Center, Natick, MA 01760, USA

$\dagger$ Electronic supplementary information (ESI) available: The synthesis of RGD modified M13, the fabrication of the thin films and supporting AFM and optical images. See DOI: 10.1039/b811039e
}

patterns were obtained with light and dark band patterns that could be directly visualized under an optical microscope (Fig. 1a). The periodic spacing of the patterns was from 1 to $4 \mu \mathrm{m}$. A mammalian cell line, NIH-3T3 mouse fibroblast, was seeded on the viral films at a density of $1.0 \times 10^{4}$ cells $\mathrm{cm}^{-2}$. The fibroblasts were maintained in Dulbecco's modified eagle's medium (DMEM) (HyClone) supplemented with $10 \%$ neonatal calf serum, $4 \mathrm{mM}$ L-glutamine, penicillin and streptomycin. NIH-3T3 cells cultured on the viral film exhibited oblong cell bodies, which extended parallel to the phage orientation (Fig. 1b and c). It can be clearly observed that the cell bodies were elongated along the long axis of the film and the nuclei of the cells were also elongated parallel to the cell body outgrowth. In contrast, NIH-3T3 fibroblast cells cultured on the normal non-virus culture surface or randomly displayed viral films showed no preferential elongation or orientation (Fig. 1d).

Although the viral films prepared by the slow-drying process generated large areas with a high level of organization, the overall orientations of the arrays were multiplex. The directionality over the entire substrate could not be controlled in a single directionality as seen in Fig. 1c. All the cells elongated along a direction, which radiated from the centre

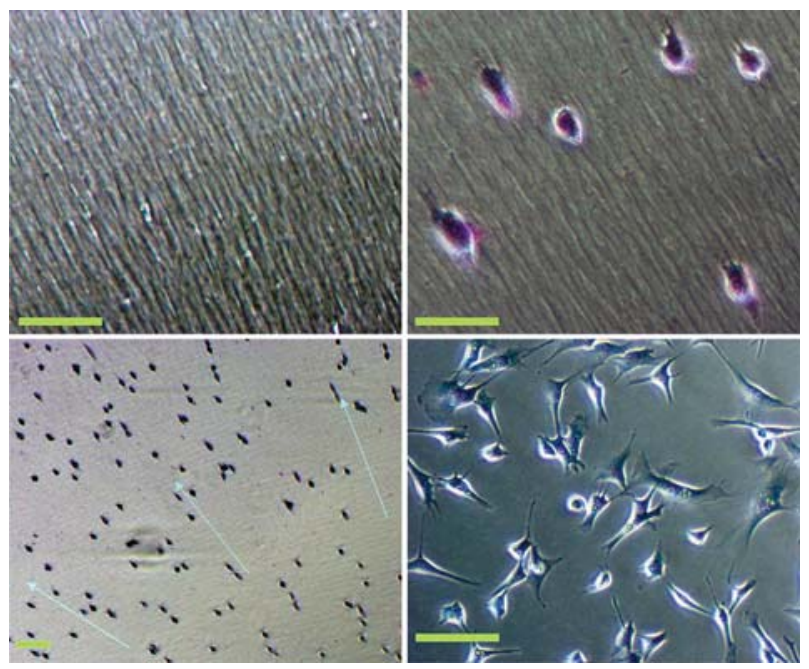

Fig. 1 Optical images using a phase contrast inverted microscope. (a) M13 thin film obtained by the slow-drying process. (b and c) NIH-3T3 cells cultured (after $4 \mathrm{~h}$ ) on an M13 thin film obtained by the slow-drying process. (d) NIH-3T3 cells cultured on a Petri dish after $24 \mathrm{~h}$. Scale bars are $50 \mu \mathrm{m}$ for (a, b and d) and $100 \mu \mathrm{m}$ for (c). The arrows in (c) point in the direction of the viral films. Cells have been stained with Giemsa to enhance cell visualization under the optical microscope. 


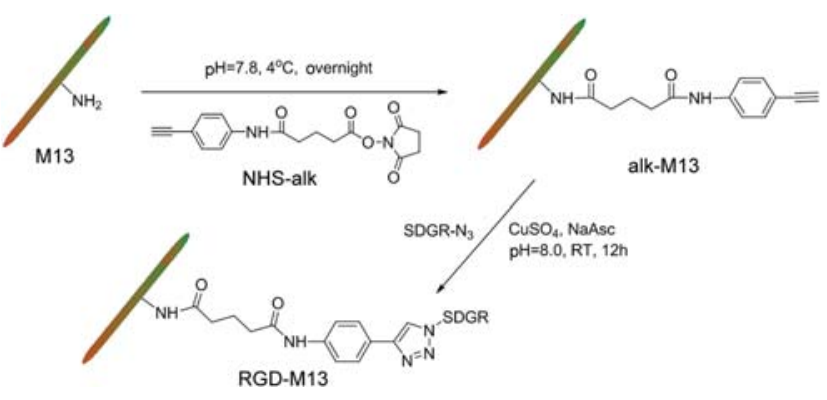

Scheme 1 Bioconjugation of M13 with RGD motifs.

of the film. Also, comparing NIH-3T3 cells cultured on a Petri dish with the cells cultured on a viral film, viral films resulted in cells that were not well stretched but round, likely due to the lack of specific cell-binding motifs on M13 thin films.

As reported in our previous study, tobacco mosaic virus (TMV) can be chemically modified with biologically relevant moieties to enhance or suppress cell adhesion. ${ }^{21}$ The RGD (Arg-Gly-Asp) tripeptide is well known to be the active sequence of adhesive proteins of the extracellular matrix, which can bind to integrin receptors of all mammalian cells. ${ }^{22,23}$ To enhance the binding between cells and M13 films, the exterior surface of M13 was conjugated with RGD motifs in order to produce biologically active materials. We had selected the amino groups on M13, which had been previously shown to be viable sites for chemical modification, to anchor RGD onto the surface of M13 in a two step procedure (Scheme 1). ${ }^{24}$ M13 was first treated with alkyne-derivatized $N$-hydroxysuccinimide ester (NHS-alk) to generate alkyne-modified M13. The alkynyl handle, as reported in the literature, has been shown to be a flexible and effective group for sequential modifications with various functionalities. $^{21,25,26}$ MALDI-TOF MS analysis indicated that $>98 \%$ of the protein subunits were decorated with one or two alkyne moieties (alk-M13) (Fig. 2). A $\mathrm{Cu}(\mathrm{I})$-catalyzed azide-alkyne 1,3-dipolar cycloaddition (CuAAC) reaction was then performed to conjugate RGD-azide to the alkyne groups. ${ }^{21}$ The CuAAC reaction was

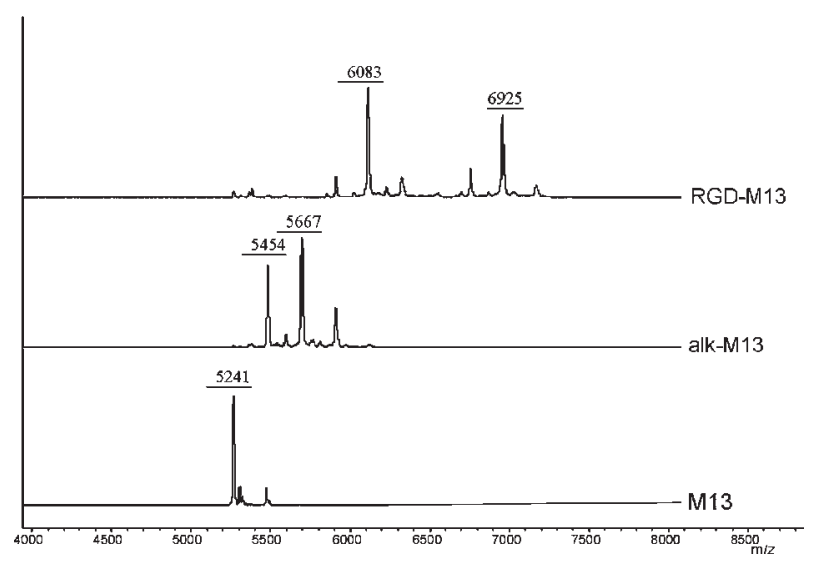

Fig. 2 MALDI-TOF MS of the coat protein P8 of unmodified M13 $(5241 \mathrm{~m} / \mathrm{z})$ and modified M13. For alk-M13, the peaks at $5454 \mathrm{~m} / \mathrm{z}$ and $5667 \mathrm{~m} / \mathrm{z}$ can be attributed to singly-modified subunits and dualmodified subunits, and the small peak at $5890 \mathrm{~m} / \mathrm{z}$ indicates a small amount of triple modification. For RGD-M13, the peaks at $6083 \mathrm{~m} / \mathrm{z}$ and $6925 \mathrm{~m} / \mathrm{z}$ correspond to single and dual RGD attachment.

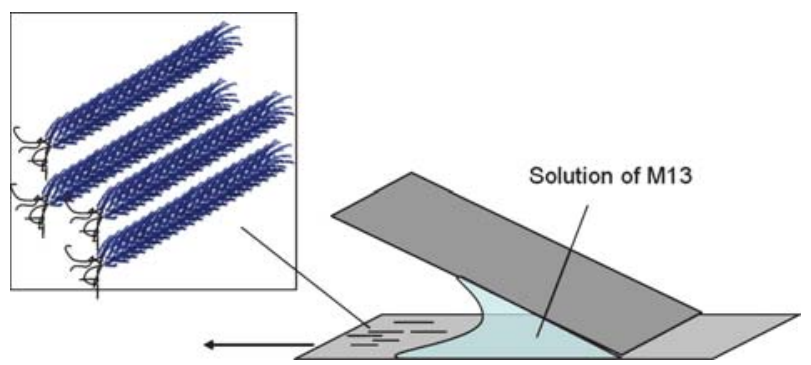

Scheme 2 Schematic representation of the system used to deposit aligned bacteriophages.

very efficient, and more than $90 \%$ of alk-M13 was transferred to RGD-modified M13 (RGD-M13).

In order to overcome the radial distribution of $2 \mathrm{D}$ viral films and generate a thin film with controlled orientation of the M13 particles, a convective assembly apparatus was used that had been previously reported for TMV alignment. ${ }^{27,28}$ Scheme 2 illustrates the general technique to prepare an aligned film of M13 on silane cover glass. Positively charged silane coated cover glass was used here to offer strong binding between the substrate and M13, which is negatively charged at neutral $\mathrm{pH}$ (the isoelectric point for M13 is around 4.4). A solution of bacteriophage M13 (20 mg ml${ }^{-1}$ ) was first deposited on the glass slide. By slowing dragging the meniscus, the virus solution formed a thin film that exhibited highly ordered M13 particles (see ESI for details $\dagger$ ). In comparison with the previous viral films obtained by the slow-drying process (Fig. 1a), light and dark banding patterns were not visible via optical microscope (data not shown). As observed by atomic force microscopy (AFM), the majority of M13 bacteriophages are directed towards one uniform direction over large areas (Fig. 3a is a $120 \mu \mathrm{m} \times 120 \mu \mathrm{m}$ AFM image). The nanoscale features of the thin film can be observed in the magnified view (Fig. 3b and Fig. S1 $\dagger$ ). RGD-modified M13 thin films are composed of a mix of M13 and RGD-M13 bacteriophage solutions at a mass ratio of 3 to 1 , respectively.

As shown in Fig. 4a (and Fig. S3a $\dagger$ ), NIH-3T3 cells cultured on these substrates had elongated and spread on these templates in a single direction. Compared with the NIH-3T3 seeded on the slowly-dried film, the cells cultured on these films display more pronounced extensions. $\beta$-Actin fibers were stained with green fluorescent phalloidin to clearly mark the alignment of the cells, which is parallel to the deposition plate withdrawing direction (Fig. 4b). We surmise that the addition

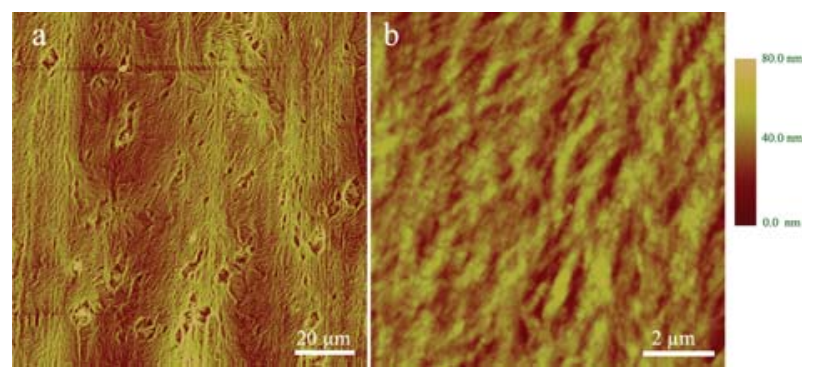

Fig. 3 Tapping mode AFM height images of aligned M13 thin film on silane coated cover glass: (a) a large scale view and (b) a magnified view. 


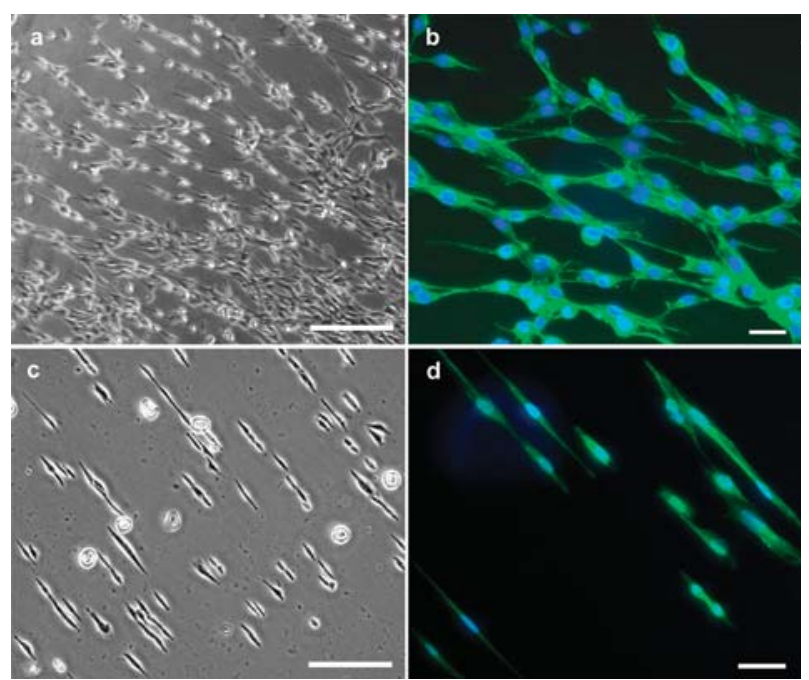

Fig. 4 Optical images using an inverted phase contrast microscope. (a) Optical image of NIH-3T3 cells cultured on an aligned M13 thin film by the slow dragging method. (b) Fluorescence image of NIH-3T3 cells. (c) Optical image of CHO cells cultured on an aligned M13 thin film by the slow dragging method. (d) Fluorescence image of $\mathrm{CHO}$ cells. $\beta$-Actin is labeled with green fluorescent phalloidin, and the nuclei with 4',6-diamidino-2-phenylindole (DAPI). Scale bars: $100 \mu \mathrm{m}$.

of RGD-modified M13 enhanced cell adhesion and spreading, since the cells cultured on non-modified films did not exhibit the extended cell bodies. Thus, by controlling the alignment of M13 particles and surface ligands, we are able to generate thin films with aligned nano-features that direct cell outgrowth along a single directionality.

In order to test the universality of the cell alignment, we cultured another mammalian cell line, Chinese hamster ovarian (CHO) cells, on the same viral films. As shown in Fig. 4c, the majority of the $\mathrm{CHO}$ cells formed similar oblong morphologies aligned in a single direction (see also Fig. S4 $\uparrow$ ). Both the fibrillar structures and the cell nuclei were stretched along the long axis of the cells (Fig. 4d). In contrast, CHO cells cultured on the nonvirus surface showed random outgrowth (data not shown).

In summary, a new scaffold based on a bacteriophage thin film has been developed for probing cell behavior. Using a slowdrying process, a high level of organization of M13 bacteriophages can be readily generated. The resulting viral films directed NIH-3T3 fibroblasts along a predictable direction; however, single direction bacteriophage thin films were better prepared by the simple withdrawing method. While both techniques had effectively aligned various mammalian cell lines, we had discovered that the withdrawal method gave the most consistent and controllable alignment of the cells. Furthermore, the surface of M13 has been chemically modified with an alkynyl group which now can be used as a universal handle to introduce various functionalities as shown previously. Different from top-down approaches to generating microstructures, such as photolithography and micro-contact printing, we utilized bacteriophages that self-assemble to generate large areas of well aligned thin film. Furthermore, this concept can be utilized in a similar fashion for other rod-like viruses (TMV and potato virus $\mathrm{X}(\mathrm{PVX})$ ) and biocompatible polymers. We are using these preliminary studies as the basis to explore neural cells and human umbilical vein endothelial cells cultured on these self-assembled viral thin films.

We are grateful for financial support from US NSF, the Alfred P. Sloan Foundation, the Camille Dreyfus TeacherScholarship, the US DoD, and the W. M. Keck Foundation. This manuscript has been approved by the US Army Natick Soldier Research, Development and Engineering Center for unlimited distribution (PAO\# 08-245).

\section{Notes and references}

1 A. Curtis and C. Wilkinson, Trends Biotechnol., 2001, 19, 97.

2 S. G. Kumbar, M. D. Kofron, L. S. Nair and C. T. Laurencin, Biomed. Nanostruct. 2008, 2008, 261.

3 R. G. Flemming, C. J. Murphy, G. A. Abrams, S. L. Goodman and P. F. Nealey, Biomaterials, 1999, 20, 573.

4 J. Y. Lim and H. J. Donahue, Tissue Eng., 2007, 13, 1879.

5 M. Théry, V. Racine, A. Pépin, M. Piel, Y. Chen, J.-B. Sibarita and M. Bornens, Nat. Cell Biol., 2005, 7, 947.

6 M. R. Dusseiller, D. Schlaepfer, M. Koch, R. Kroschewski and M. Textor, Biomaterials, 2005, 26, 5917.

7 L. Lauer, C. Klein and A. Offenhausser, Biomaterials, 2001, 22, 1925.

8 I. Daniel and T. Mehmet, Lab Chip, 2006, 6, 345.

9 R. Murugan and S. Ramakrishna, Tissue Eng., 2006, 12, 435.

10 L. A. Lee and Q. Wang, Nanomedicine, 2006, 2, 137.

11 Y. Ren, S. M. Wong and L. Y. Lim, Bioconjugate Chem., 2007, 18, 836.

12 Selected papers: T. Douglas and M. Yong, Nature, 1998, 393, 152; C. E. Flynn, S.-W. Lee, B. R. Peelle and A. M. Belcher, Acta Mater., 2003, 51, 5867; A. S. Blum, C. M. Soto, C. D. Wilson, T. L. Brower, S. K. Pollack, T. L. Schull, A. Chatterji, T. Lin, J. E. Johnson, C. Amsinck, P. Franzon, R. Shashidhar and B. R. Ratna, Small, 2005, 1, 702; T. Douglas and M. Yong, Science, 2006, 312, 873; M. Fischlechner, U. Reibetanz, M. Zaulig, D. Enderlein, J. Romanova, S. Leporatti, S. Moya and E. Donath, Nano Lett., 2007, 7, 3540.

13 Representative works from our group: Y. Lin, A. Boker, J. He, K. Sill, H. Xiang, C. Abetz, X. Li, J. Wang, T. Emrick, S. Long, Q. Wang, A. Balazs and T. P. Russell, Nature, 2005, 434, 55; J. Russell, Y. Lin, A. Böker, S. Long, P. Carl, H. Zettl, J. He, K. Sill, R. Tangirala, T. Emrick, K. Littrell, P. Thiyagarajan, D. Cookson, A. Fery, Q. Wang and T. P. Russell, Angew. Chem., 2005, 117, 2472; Z. Niu, M. A. Bruckman, V. S. Kotakadi, J. He, T. Emrick, T. P. Russell, L. Yang and Q. Wang, Chem. Commun., 2006, 3019 .

14 S. R. Whaley, D. S. English, E. L. Hu, P. F. Barbara and A. M. Belcher, Nature, 2000, 405, 665.

15 P. J. Yoo, K. T. Nam, J. Qi, S.-K. Lee, J. Park, A. M. Belcher and P. T. Hammond, Nat. Mater., 2006, 5, 234.

16 S.-W. Lee, B. M. Wood and A. M. Belcher, Langmuir, 2003, 19, 1592.

17 S.-W. Lee and A. M. Belcher, Nano Lett., 2004, 4, 387.

18 S.-W. Lee, S. K. Lee and A. M. Belcher, Adv. Mater., 2003, 15, 689.

19 S.-W. Lee, C. Mao, C. E. Flynn and A. M. Belcher, Science, 2002, 296, 892.

20 G. Eric and F. Seth, Phys. Rev. Lett., 2003, 90, 198302.

21 M. A. Bruckman, G. Kaur, L. A. Lee, F. Xie, J. Sepulveda, R. Breitenkamp, X. Zhang, M. Joralemon, T. P. Russell, T. Emrick and Q. Wang, ChemBioChem, 2008, 9, 519.

22 Y. K. Liu, A. Nemoto, Y. Feng and T. Uemura, J. Biochem. (Tokyo, Jpn), 1997, 121, 961.

23 E. Ruoslahti and M. D. Pierschbacher, Science, 1987, 238, 491.

24 G. C. Ford, P. M. Harrison, D. W. Rice, J. M. A. Smith, A. Treffry, J. L. White and J. Yariv, Philos. Trans. R. Soc. London, Ser. B, 1984, 304, 551.

25 Q. B. Zeng, T. Li, B. Cash, S. Q. Li, F. Xie and Q. Wang, Chem. Commun., 2007, 1453.

26 Q. Wang, T. Chan, R. Hilgraf, V. V. Fokin, K. B. Sharpless and M. G. Finn, J. Am. Chem. Soc., 2003, 125, 3192.

27 D. M. Kuncicky, R. R. Naik and O. D. Velev, Small, 2006, 2, 1462.

28 S. P. Wargacki, B. Pate and R. A. Vaia, Langmuir, 2008, 24, 5439. 